\title{
The experiences of family caregivers living with breast cancer patients in low-and middle-income countries: a systematic review
}

Grace Kusi ${ }^{1,2}$, Adwoa Bemah Boamah Mensah ${ }^{1 *}$, Kofi Boamah Mensah ${ }^{3,4}$, Veronica Millicent Dzomeku', Felix Apiribu ${ }^{1}$, Precious Adade Duodu', Bakinam Adamu', Pascal Agbadi ${ }^{1}$ and Kwadwo Osei Bonsu ${ }^{4}$

\begin{abstract}
Introduction: Caregivers of women with breast cancer in low-and-middle-income countries experience significant physical and economic burdens. The review aimed to map the evidence of studies that had reported on the experiences of family caregivers of women diagnosed with breast cancer.

Methods: A systematic literature search was conducted in CINAHL, PubMed, PsycINFO, Scopus, and Web of Science databases using a combination of key search terms and medical subject heading terms such as "family caregiver," "breast cancer," "home care," "low-and-middle-income countries," "experience," "effect," and "coping mechanism." A total of 1781 articles were retrieved and screened. Nineteen studies addressing caregiving experiences were included in the final review based on the inclusion and exclusion criteria.

Results: The systematic review yielded 19 studies that focused on caregivers' motivation, needs of caregivers, intervention for caregivers, and consequences of caregiving. The most significant correlates of the quality of life among caregivers were disease severity, functional status of patients, and family income. The challenges encountered by caregivers were mostly psychosocial.
\end{abstract}

Conclusions: Caregivers play a crucial role in the management of women with breast cancer. However, they are faced with increasing challenges in their caregiving roles. Understanding the nature and extent of the burden experienced by family caregivers in developing countries will facilitate the development of appropriate interventions that can help improve caregivers' quality of life. Gaps in recent studies were identified, and suggestions for future research were also addressed in this review.

Systematic review registration: PROSPERO CRD42019118391

Keywords: Breast cancer, Family caregiver, Low- and middle-income countries, Experiences

\footnotetext{
* Correspondence: bbemahc2000@gmail.com

'Department of Nursing, Faculty of Allied Health Sciences, College of Health

Sciences, Kwame Nkrumah University of Science and Technology, Kumasi,

Ghana

Full list of author information is available at the end of the article
}

(c) The Author(s). 2020 Open Access This article is licensed under a Creative Commons Attribution 4.0 International License, which permits use, sharing, adaptation, distribution and reproduction in any medium or format, as long as you give appropriate credit to the original author(s) and the source, provide a link to the Creative Commons licence, and indicate if changes were made. The images or other third party material in this article are included in the article's Creative Commons licence, unless indicated otherwise in a credit line to the material. If material is not included in the article's Creative Commons licence and your intended use is not permitted by statutory regulation or exceeds the permitted use, you will need to obtain permission directly from the copyright holder. To view a copy of this licence, visit http://creativecommons.org/licenses/by/4.0/ The Creative Commons Public Domain Dedication waiver (http://creativecommons.org/publicdomain/zero/1.0/) applies to the data made available in this article, unless otherwise stated in a credit line to the data. 


\section{Introduction}

The increasing incidence and mortality rate of breast cancer has produced challenges in caring for women with breast cancer, especially in low- and middle-income countries (LMICs) [1, 2]. This challenge has implications for relatives and friends who become family caregivers [3]. Breast cancer treatment is now shifting from an inpatient setting to a more outpatient setting due to contextual barriers to oncology services that exist in LMICs, such as limited availability of treatment facilities, lack of cancer specialists [4], and limited geographical access to oncology care [5]. This shift has resulted in the role of family caregivers as significant members of the cancer care system who are expected to provide physical, emotional, financial, and psychosocial support to women diagnosed with breast cancer in the home setting [6-9]. However, according to Khanjari et al. [10], the current declining socioeconomic trends in LMICs potentially alter the capacity of caregivers to meet the growing demand for home care support for women with breast cancer.

The burden of breast cancer caregiving includes emotional distress, financial burden, physical stress, and fear of uncertainty among caregivers [11-13]. Furthermore, the advanced stage disease presentation, a hallmark of this disease in LMICs, can result in increased psychosocial morbidity, poor physical health, and overall poor quality of life among caregivers [6, 10, 11, 14]. Hashemi-Ghasemabadi et al. [6] have indicated that caregivers who deliver care to women with breast cancer in LMICs experience unique challenges due to under-resourced and limited cancer support systems. For instance, few West African studies focusing on this phenomenon have highlighted that challenges encountered by caregivers include loss of job, difficulty in balancing multiple roles, a decline in physical health, lack of access to healthcare funding, emotional trauma, and lack of information in managing breast cancer-related symptoms such as wound and lymphedema [4, 15]. A recent Ghanaian study reporting on the motivation and caregiving experiences of family caregivers of advanced breast cancer patients showed that sociocultural obligation and reciprocity were the main reasons for assuming the caregiving role [4]. Further, the study also highlighted that caregivers provided multi-dimensional forms of support such as physical, psychosocial, emotional, financial, symptom management, and spiritual support for women living with advanced breast cancer. Financial burden through the provision of out-ofpocket money for treatment costs and other related non-medical costs were the main challenge reported by participants in this study [4]. The study recommended home-based support programs and direct governmental social intervention programs to assist caregivers in their caring role.
However, to date, no systematic review of family caregiving in breast cancer that is specific to LMICs has been conducted to fully understand the experiences and challenges faced by this group of caregivers. Exploring the experiences of family caregivers is critical in providing potential interventions that can aid in addressing the needs of family caregivers in LMICs. Hence, the rationale of this systematic review was to summarize and appraise existing evidence on studies that had reported on:

(a) Home care experiences of caregivers of women diagnosed with breast cancer in LMICs.

(b) Effects of caregiving on the family caregivers in LMICs.

(c) Coping mechanisms utilized by family caregivers of women living with breast cancer in LMICs.

\section{Materials and methods}

The protocol of this review is duly registered (CRD42019118391) in the PROSPERO international prospective register of systematic reviews. Studies that explored the experiences of caregivers living with breast cancer patients in LMICs were searched.

\section{Inclusion and exclusion criteria}

All studies (quantitative studies, qualitative studies, and mixed-method studies) were conducted in diverse settings such as hospitals or communities published from January 2000 to March 2020. Other criteria for inclusion were (1) family caregivers of breast cancer patients aged 18 years and above, (2) providing non-paid caregiving services to breast cancer patients, (3) full-text published articles from LMICs (low-and-middle-income country was operationalized in this study as low-, lower-middle, and upper-middle-income economy based on the January 2020 World Bank list of analytical income classification of economies) [16], (4) reporting on family caregivers experiences, and (5) articles published in the English language.

\section{Exclusion criteria}

Studies were excluded from this review based on the following criteria: (1) focused on paid and formal caregivers such as healthcare professionals; (2) not published in the English language (due to limited availability of translation service to the authors); and lastly, (3) systematic reviews, abstracts, editorial reports, letters, conference articles, and gray literatures with no full-text published articles were excluded because they were not considered as scientific published articles.

\section{Search strategy}

A systematic review was conducted according to the Preferred Reporting Items for Systematic Review and 
Meta-Analysis Protocols (PRISMA-P). We conducted a comprehensive search of qualitative, quantitative, and mixed-methods literature that was published from January 2000 to March 2020 in the electronic databases, i.e., PubMed, CINAHL, Scopus, Web of Science, and PsycINFO, to retrieve all English language literature that contained information on family caregivers of breast cancer patients in low- and middle-income countries. As previously defined, studies were defined into "low-income," "lower-middle-income," and "upper-middle-income" countries as categorized by the World Bank [16]. Primary concepts such as "family caregiver," "breast cancer," "home care," "low-and-middle-income-countries," "experience," "effect," and "coping" and their Medical Subject Headings (MESH) were used for the search (Additional file 1: Table S1). The subject search and text word search were performed separately in all the databases and then combined with Boolean operators "OR" and "AND." Combined terms used, for example, were ("Caregiv"(MESH)" OR "Family caregiv (MESH)*") AND ("Breast cancer (MESH)" OR "Breast neoplasm"(MESH)") AND ("low-income countr*[tw]" OR "lowermiddle-income countr*[tw]"). Additional articles were searched from other sources such as Google Scholar as well as hand-searching the references of all included studies. This produced three additional articles from Google Scholar [17-19].

\section{Literature screening}

Following the literature search, citations were imported into Mendeley Desktop (version 1.19.4) reference manager for storage and screening of articles as well as the removal of duplicates. The remaining articles were then screened independently by titles and abstracts. Two reviewers (GK and $\mathrm{KBM}$ ) screened all the citations that were identified from the search using standard systematic review procedures (inclusion and exclusion criteria). Any disagreement was resolved by discussion and consensus or by consulting a third reviewer $(\mathrm{ABBM})$ where needed.

\section{Quality appraisal or assessment tool}

The quality of the selected studies was assessed independently by GK and KBM using the Mixed Methods Appraisal Tool (MMAT) version 2018 [20]. This tool has been developed to evaluate qualitative, quantitative, and mixed-method studies using two screening questions and four methodological criteria. The tool assesses the appropriateness of the aim of the study, adequacy and methodology, study design, participant recruitment, data collection, data analysis, presentation of findings, authors' discussions, and conclusions [21]. Each question carries three possible responses: "yes," "no," or" can't tell." A star is assigned (four stars maximum possible score) to each yes response and is converted to percentages (from one star $=25 \%$ to four stars $=100 \%$ ) [20]. Using the aforementioned domains, score from 0$25 \%$ is regarded as weak, $50 \%$ is regarded as moderate, $75 \%$ is regarded as moderate-strong, and $100 \%$ is regarded as strong [20].

The interrater reliability for each MMAT dimension for quality ratings of the included studies was evaluated using Cohen's kappa statistic [22]. This was done to assess the level of agreement of quality ratings between the two independent authors (GK and KBM) who performed the quality assessment for the included studies. The interrater reliability of each MMAT dimension was assessed and reported as Cohen's kappa coefficient and 95\% confidence interval $(95 \% \mathrm{CI})$ with two-sided $p$ value. Acceptable kappa values $0.80-0.90,>0.90$, and 1.0 represent strong, almost perfect, and excellent levels of agreement between raters [22].

\section{Data extraction and analysis}

Two reviewers (GK and KBM) independently extracted key characteristics from the included articles: bibliographic information (authors' name, year of publication, country, and address). Others included the methodology (study aim, design, setting, and sample size), caregivers' characteristics, and major findings on caregivers' experiences, conclusions, and limitations of the study as described in Table 1. There was significant heterogeneity in the measurement of the outcomes of the eligible studies, making it impossible to pool data in a meta-analysis. Therefore, a narrative analysis or strategy was employed to synthesize the evidence.

\section{Results}

\section{Literature search results}

Only articles that had reported on family caregivers of breast cancer patients in low- and middle-income countries were included. The initial search returned 1781 records. A total of 430 duplicates were removed using the Mendeley Desktop (version 1.19.4). The remaining 1351 records were screened for titles and abstracts by the two independent reviewers ( $\mathrm{GK}$ and $\mathrm{KBM}$ ). We then excluded 1225 articles, and a full-text screening was done on the remaining 126 articles. Following the full-text screening, 107 were excluded because they did not meet the inclusion criteria as detailed in the PRISMA flow diagram. At the end of the screening procedure, 19 peer-reviewed citations remained for final inclusion in the review $[3,4,6,10,15,17-19,23-33]$.

A schema illustrating the screening process is shown in Fig. 1.

\section{Methodological characteristics of included studies}

The majority of the included studies $(n=15)$ used quantitative approaches $[3,10,15,18,19,23-28,30-33]$ and 
Table 1 Summary of study characteristics and findings

\begin{tabular}{|c|c|c|c|c|c|c|c|}
\hline Author/year & Country & $\begin{array}{l}\text { Aim/research } \\
\text { questions }\end{array}$ & Study design & Caregivers & Findings & Conclusion & Limitation \\
\hline $\begin{array}{l}\text { Vahidi et al. } \\
\text { (2016) [3] }\end{array}$ & Iran & $\begin{array}{l}\text { Determine factors } \\
\text { associated with } \\
\text { caregiver burden } \\
\text { among primary } \\
\text { caregivers of } \\
\text { women with } \\
\text { breast cancer }\end{array}$ & $\begin{array}{l}\text { Descriptive } \\
\text { correlation study }\end{array}$ & $\begin{array}{l}150 \text { primary } \\
\text { caregivers; } \\
\text { caregivers mean } \\
\text { age } 39.60 \text { years; } \\
77(51.3 \%) \text { were } \\
\text { males }\end{array}$ & $\begin{array}{l}\text { Caregivers assisted } \\
\text { with activities of } \\
\text { daily living, } \\
\text { administering } \\
\text { medication, } \\
\text { symptom } \\
\text { management, and } \\
\text { financial support. } \\
\text { Higher caregiver } \\
\text { burden was } \\
\text { associated with } \\
\text { increasing } \\
\text { assistance with } \\
\text { activities of daily } \\
\text { living, low } \\
\text { educational level, } \\
\text { gender, and poor } \\
\text { financial status }\end{array}$ & $\begin{array}{l}\text { Caregivers must } \\
\text { be provided with } \\
\text { comprehensive } \\
\text { care needs } \\
\text { support. Primary } \\
\text { caregivers need to } \\
\text { be supported } \\
\text { financially by } \\
\text { relevant } \\
\text { organizations, } \\
\text { such as } \\
\text { government } \\
\text { agencies and } \\
\text { charities. Other } \\
\text { factors such as } \\
\text { dedicating a place } \\
\text { for caregivers in } \\
\text { the clinic to } \\
\text { receive care skills } \\
\text { training from } \\
\text { expert nurses can } \\
\text { be effective }\end{array}$ & $\begin{array}{l}\text { Cross-sectional } \\
\text { studies do not } \\
\text { show the } \\
\text { difference in } \\
\text { burden in } \\
\text { response to } \\
\text { cancer } \\
\text { progression in the } \\
\text { patient; therefore, } \\
\text { longitudinal } \\
\text { studies are } \\
\text { recommended }\end{array}$ \\
\hline $\begin{array}{l}\text { Gabriel, Aluko } \\
\text { and Okeme } \\
\text { (2019) [15] }\end{array}$ & Nigeria & $\begin{array}{l}\text { Impact of } \\
\text { caregiving burden } \\
\text { on the informal } \\
\text { caregivers of } \\
\text { women with } \\
\text { breast cancer }\end{array}$ & Descriptive study & $\begin{array}{l}118 \text { caregivers; } \\
\text { mean age = } \\
41.9 \text { years. Most } \\
\text { were child ( } 77.1 \%), \\
\text { spouse }(14.4 \%) \\
\text { and others }(8.5 \%)\end{array}$ & $\begin{array}{l}\text { Determinants of } \\
\text { high caregiver } \\
\text { burden were } \\
\text { payment type for } \\
\text { treatment, family } \\
\text { income, } \\
\text { relationship to the } \\
\text { patient, social } \\
\text { support, and self- } \\
\text { efficacy }\end{array}$ & $\begin{array}{l}\text { Strategies to } \\
\text { improve self- } \\
\text { efficacy such as } \\
\text { additional training, } \\
\text { follow-up, peer } \\
\text { education, and } \\
\text { support groups } \\
\text { for caregivers } \\
\text { might decrease } \\
\text { the caregiver } \\
\text { burden }\end{array}$ & $\begin{array}{l}\text { Use of } \\
\text { convenience } \\
\text { sampling making } \\
\text { it difficult to } \\
\text { identify causal } \\
\text { relationships }\end{array}$ \\
\hline $\begin{array}{l}\text { Zhu et al. } \\
\text { (2014) [31] }\end{array}$ & China & $\begin{array}{l}\text { To assess the } \\
\text { quality of life in } \\
\text { male spouse } \\
\text { caregivers }\end{array}$ & $\begin{array}{l}\text { Cross-sectional } \\
\text { study }\end{array}$ & $\begin{array}{l}243 \text { spouse } \\
\text { caregivers. Mean } \\
\text { age }=49.5 \text { years }\end{array}$ & $\begin{array}{l}\text { Decreasing patient } \\
\text { functional status } \\
\text { was significantly } \\
\text { associated with } \\
\text { poor quality of life } \\
\text { among caregivers. } \\
\text { High family } \\
\text { income and } \\
\text { longer sleeping } \\
\text { time increased the } \\
\text { quality of life } \\
\text { among caregivers }\end{array}$ & $\begin{array}{l}\text { Attention should } \\
\text { be paid to male } \\
\text { spouse caregivers } \\
\text { as a separate } \\
\text { group. Nurses can } \\
\text { understand the } \\
\text { status of caregiver } \\
\text { burden and QOL } \\
\text { by assessing both } \\
\text { patients and } \\
\text { spouses. The } \\
\text { mental health of } \\
\text { spouse caregivers } \\
\text { was disrupted } \\
\text { more seriously } \\
\text { than the physical } \\
\text { health }\end{array}$ & $\begin{array}{l}\text { The study focused } \\
\text { on spouse } \\
\text { caregivers and } \\
\text { hence cannot be } \\
\text { generalized for } \\
\text { other non-spousal } \\
\text { caregivers }\end{array}$ \\
\hline $\begin{array}{l}\text { Hashemi- } \\
\text { Ghasemabadi } \\
\text { et al. (2016) } \\
\text { [6] }\end{array}$ & Iran & $\begin{array}{l}\text { Transition to the } \\
\text { new role of } \\
\text { caregiving for } \\
\text { families of women } \\
\text { with breast cancer } \\
\text { diagnosis }\end{array}$ & $\begin{array}{l}\text { Qualitative } \\
\text { descriptive } \\
\text { exploratory study }\end{array}$ & $\begin{array}{l}23 \text { caregivers. } \\
\text { Mean age }= \\
37.5 \text { years. } 69.6 \% \\
\text { were females and } \\
30.4 \% \text { men }\end{array}$ & $\begin{array}{l}\text { Emerged themes: } \\
\text { "Grasping a new } \\
\text { situation without } \\
\text { preparation" } \\
\text { "Perceived } \\
\text { inefficiency" } \\
\text {."Infinite absence" } \\
\text { "Abandoned in } \\
\text { the role" } \\
\text { Caregivers cited } \\
\text { that they were } \\
\text { unprepared for } \\
\text { their new role and } \\
\text { did not have the } \\
\text { necessary skills } \\
\text { and knowledge to }\end{array}$ & $\begin{array}{l}\text { By understanding } \\
\text { their experiences } \\
\text { in the transition to } \\
\text { the new role, it is } \\
\text { possible to } \\
\text { provide detailed } \\
\text { information for } \\
\text { designing } \\
\text { evidence-based } \\
\text { healthcare inter- } \\
\text { ventions and } \\
\text { comprehensive } \\
\text { family-centered } \\
\text { care program. } \\
\text { Also, interventions } \\
\text { can be tailored to }\end{array}$ & $\begin{array}{l}\text { Study could not } \\
\text { be generalized } \\
\text { because it is a } \\
\text { qualitative study. } \\
\text { Provided limited } \\
\text { information on } \\
\text { coping strategies }\end{array}$ \\
\hline
\end{tabular}


Table 1 Summary of study characteristics and findings (Continued)

Findings Conclusion Limitation

\begin{tabular}{|c|c|c|c|c|}
\hline Author/year & Country & $\begin{array}{l}\text { Aim/research } \\
\text { questions }\end{array}$ & Study design & Caregivers \\
\hline $\begin{array}{l}\text { Sahadevan } \\
\text { et al. (2019) } \\
\text { [26] }\end{array}$ & India & $\begin{array}{l}\text { Identify the } \\
\text { determinants of } \\
\text { depression among } \\
\text { caregivers of } \\
\text { patients with } \\
\text { breast cancer }\end{array}$ & $\begin{array}{l}\text { Cross-sectional } \\
\text { survey }\end{array}$ & $\begin{array}{l}384 \text { caregivers. } \\
\text { Mean age }= \\
47.25 \text { years. } 163 \\
(42.4 \%) \text { were } \\
\text { males }\end{array}$ \\
\hline
\end{tabular}

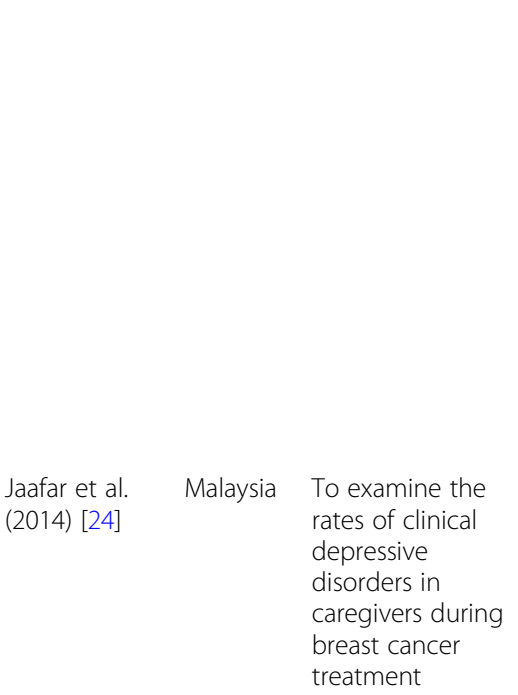

Gabriel and

Nigeria

Mayers (2019)

[27]

$\begin{array}{ll}\text { Cross-sectional } & 130 \text { caregivers } \\ \text { study } & \text { comprising of } \\ & \text { spouses (46.9\%), } \\ & \text { children (40.0\%), } \\ & \text { and siblings } \\ & (13.1 \%)\end{array}$

Depressive

related to low

educational status

high duration of caregiving

\section{To assess the} effectiveness of a psychosocial

intervention in reducing caregiver burden among caregivers manage breast

cancer and its

related symptoms.

Caregiving was

also described as

a time-consuming

role which com-

peted with other

family roles and

responsibilities.

Higher financial responsibilities,

being a spousal

caregiver are

important

determinants of

depression among

caregivers

disorders were

of caregivers and

the objectives and resource limita-

tions, for the sup-

port and

resolution of the

challenges of care-

givers to decrease

the negative con-

sequences of

caregiving

Cancer specialists

in treatment team

need to be aware

of the need for

psychological

assessment of

principal

caregivers. They

should be trained

to pick up

depressive

symptoms and its

associated risk

factors at the

earliest and

should be offered

services to the

needful. This

approach

ultimately

improves the

outcome of

cancer treatment

This finding gives

clues to

intervening

Data on coping mechanism were missing in this

depression among study. The study

the caregivers by was conducted in

providing support a single facility

in the form of

which might limit

respite care to the generalizability to

caregivers and

improving

engagement of

the caregivers by

the health care

providers. The

results should

increase the

health care

providers'

awareness of the

vulnerability of

this population

and discard a

patient-centric ap-

proach of

treatment Primary caregivers
who received the

intervention $\quad$ who received th

group (54). intervention

Caregivers were reported

primarily spouse

(30.6\%), parent

significant

decrease in

The need for effective advocacy on the issue of caregiver burden is vital. Relevant

stakeholders in

the healthcare similar population

(15.7\%), sibling

burden at 6 weeks sector, especially
Non-randomized deign was used to recruit participants. Psychosocial intervention did not address the subjective aspect 
Table 1 Summary of study characteristics and findings (Continued)

\begin{tabular}{|c|c|c|c|c|c|c|c|}
\hline Author/year & Country & $\begin{array}{l}\text { Aim/research } \\
\text { questions }\end{array}$ & Study design & Caregivers & Findings & Conclusion & Limitation \\
\hline & & & & $\begin{array}{l}\text { (17.6\%), child } \\
(21.3 \%) \text {, and friend } \\
(14.8 \%)\end{array}$ & $\begin{array}{l}\text { and } 12 \text { weeks. } \\
\text { Further, the } \\
\text { psychosocial } \\
\text { intervention also } \\
\text { improved the } \\
\text { overall quality of } \\
\text { life of caregivers }\end{array}$ & $\begin{array}{l}\text { in palliative care, } \\
\text { should conduct } \\
\text { advocacy } \\
\text { campaigns to } \\
\text { promote the } \\
\text { culture of caring } \\
\text { and support for } \\
\text { the person with } \\
\text { cancer and the } \\
\text { caregiver }\end{array}$ & $\begin{array}{l}\text { of the caregiver } \\
\text { burden }\end{array}$ \\
\hline $\begin{array}{l}\text { Giray and } \\
\text { Akyuz (2019) } \\
{[28]}\end{array}$ & Turkey & $\begin{array}{l}\text { To assess } \\
\text { relationships } \\
\text { between caregiver } \\
\text { burden, quality of } \\
\text { life, arm disability, } \\
\text { grip strength, and } \\
\text { lymphedema } \\
\text { symptoms in } \\
\text { patients with } \\
\text { postmastectomy } \\
\text { lymphedema }\end{array}$ & $\begin{array}{l}\text { Prospective cross- } \\
\text { sectional study }\end{array}$ & $\begin{array}{l}52 \text { caregivers. } \\
\text { Mean age }=48.46 \\
\text { years. } 14(26.9 \%) \\
\text { were females and } \\
38(73.1 \%) \text { were } \\
\text { males }\end{array}$ & $\begin{array}{l}\text { Caregiver burden } \\
\text { was associated } \\
\text { with arm disability } \\
\text { and quality of life } \\
\text { of these patients. } \\
\text { Arm disability } \\
\text { affects caregiver } \\
\text { burden and } \\
\text { quality of life in } \\
\text { these patients. } \\
\text { Arm disability was } \\
\text { higher in patients } \\
\text { at stage } 3 \\
\text { lymphedema than } \\
\text { patients at milder } \\
\text { stages }\end{array}$ & $\begin{array}{l}\text { Arm disability } \\
\text { should be } \\
\text { diagnosed and } \\
\text { treated to } \\
\text { improve caregiver } \\
\text { burden and } \\
\text { quality of life }\end{array}$ & $\begin{array}{l}\text { This was an } \\
\text { observational } \\
\text { study using a } \\
\text { convenience } \\
\text { sample. } \\
\text { Comparison of } \\
\text { caregiver burden } \\
\text { before and after } \\
\text { lymphedema } \\
\text { development and } \\
\text { treatment can } \\
\text { more enlighten } \\
\text { the importance of } \\
\text { caregiver burden } \\
\text { in the } \\
\text { management of } \\
\text { patients with } \\
\text { postmastectomy } \\
\text { lymphedema }\end{array}$ \\
\hline $\begin{array}{l}\text { Moreno- } \\
\text { Gonzalez } \\
\text { et al. (2019) } \\
{[29]}\end{array}$ & Mexico & $\begin{array}{l}\text { To describe the } \\
\text { experience of } \\
\text { family care of } \\
\text { women with } \\
\text { breast cancer } \\
\text { during treatment } \\
\text { from the } \\
\text { perspective of } \\
\text { caregivers }\end{array}$ & Qualitative study & $\begin{array}{l}\text { Seven caregivers } \\
\text { ( } 3 \text { men and } 4 \\
\text { women) }\end{array}$ & $\begin{array}{l}\text { Male caregivers } \\
\text { stated that the } \\
\text { absence of a } \\
\text { breast did not } \\
\text { interfere with the } \\
\text { perception of their } \\
\text { femininity or } \\
\text { sexual } \\
\text { attractiveness. } \\
\text { Caregivers } \\
\text { experienced fear } \\
\text { and despair for } \\
\text { not knowing how } \\
\text { to alleviate } \\
\text { women } \\
\text { symptoms. Also, } \\
\text { caregivers } \\
\text { experienced fear } \\
\text { of the unknown } \\
\text { and sometimes } \\
\text { anger. They also } \\
\text { looked for } \\
\text { strategies to } \\
\text { maintain their } \\
\text { emotional } \\
\text { balance. Female } \\
\text { caregivers living } \\
\text { this experience } \\
\text { expressed a } \\
\text { greater perception } \\
\text { of the risk of } \\
\text { suffering from } \\
\text { breast cancer, } \\
\text { which favored } \\
\text { their self-care by } \\
\text { knowing about } \\
\text { the timely }\end{array}$ & $\begin{array}{l}\text { The experience of } \\
\text { caregivers of } \\
\text { women with } \\
\text { breast cancer } \\
\text { generated } \\
\text { profound changes } \\
\text { in them through } \\
\text { the discovery of } \\
\text { their reach and } \\
\text { limitations in } \\
\text { difficult situations } \\
\end{array}$ & $\begin{array}{l}\text { The study leaves } \\
\text { aside different } \\
\text { contexts and } \\
\text { events such as } \\
\text { rupture between } \\
\text { couple and family } \\
\text { disintegration that } \\
\text { may prevail }\end{array}$ \\
\hline
\end{tabular}


Table 1 Summary of study characteristics and findings (Continued)

\begin{tabular}{|c|c|c|c|c|c|c|c|}
\hline Author/year & Country & $\begin{array}{l}\text { Aim/research } \\
\text { questions }\end{array}$ & Study design & Caregivers & Findings & Conclusion & Limitation \\
\hline & & & & & \multicolumn{3}{|l|}{ detection } \\
\hline $\begin{array}{l}\text { Wulandari } \\
\text { et al. (2017) }\end{array}$ & Indonesia & $\begin{array}{l}\text { Determine the } \\
\text { experience of } \\
\text { stress and } \\
\text { adaptation of } \\
\text { breast cancer } \\
\text { patient's family }\end{array}$ & Qualitative method & 7 male caregivers & $\begin{array}{l}\text { Caregivers cited } \\
\text { that they } \\
\text { experience } \\
\text { stressors related to } \\
\text { difficulty in } \\
\text { managing of the } \\
\text { disease and the } \\
\text { financial needs of } \\
\text { the patient. } \\
\text { Caregivers further } \\
\text { reported that } \\
\text { financial problem } \\
\text { became a stressor } \\
\text { from the } \\
\text { beginning until } \\
\text { the end of the } \\
\text { breast cancer } \\
\text { treatment. } \\
\text { Components of } \\
\text { caregiver coping } \\
\text { mechanism } \\
\text { consisted of } \\
\text { strategies such as } \\
\text { emotional support } \\
\text { from health } \\
\text { professionals, } \\
\text { prayer, and } \\
\text { gratitude }\end{array}$ & $\begin{array}{l}\text { The experience of } \\
\text { stress and } \\
\text { adaptation of the } \\
\text { family of breast } \\
\text { cancer patients is } \\
\text { a continuous } \\
\text { stage. Continued } \\
\text { coping such as } \\
\text { support from } \\
\text { professional } \\
\text { nurses may be } \\
\text { needed to } \\
\text { minimize the } \\
\text { stress and } \\
\text { improve } \\
\text { adaptation of } \\
\text { family caregivers }\end{array}$ & $\begin{array}{l}\text { Caregivers in this } \\
\text { study was small. } \\
\text { Study did not } \\
\text { explain } \\
\text { comprehensively } \\
\text { measures that } \\
\text { were undertaken } \\
\text { to ensure } \\
\text { trustworthiness of } \\
\text { the study }\end{array}$ \\
\hline $\begin{array}{l}\text { Bahrami and } \\
\text { Farzi (2014) } \\
\text { [18] }\end{array}$ & Iran & $\begin{array}{l}\text { Determine the } \\
\text { effect of a } \\
\text { supportive } \\
\text { educational } \\
\text { program on the } \\
\text { caregiving burden } \\
\text { and quality of life } \\
\text { in the family } \\
\text { caregivers of } \\
\text { women with } \\
\text { breast cancer }\end{array}$ & $\begin{array}{l}\text { Two-group } \\
\text { two-step before- } \\
\text { after clinical trial }\end{array}$ & $\begin{array}{l}64 \text { family } \\
\text { caregivers. Mean } \\
\text { age (control } \\
\text { group) }=38.97 \\
\text { Mean age } \\
\text { (experimental } \\
\text { group) }\end{array}$ & $\begin{array}{l}\text { The study } \\
\text { implemented a } \\
\text { supportive } \\
\text { educational } \\
\text { program to a } \\
\text { group of } \\
\text { caregivers. After } \\
\text { the intervention } \\
\text { has been } \\
\text { implemented, the } \\
\text { results showed } \\
\text { that in the } \\
\text { experimental } \\
\text { group, the mean } \\
\text { score of physical, } \\
\text { mental, spiritual, } \\
\text { and } \\
\text { environmental } \\
\text { domains and } \\
\text { overall quality of } \\
\text { life in the family } \\
\text { caregivers was } \\
\text { significantly } \\
\text { increased } \\
\text { compared to the } \\
\text { control group. } \\
\text { Further, in the } \\
\text { experimental } \\
\text { group, the mean } \\
\text { score of caring } \\
\text { burden among } \\
\text { the caregivers was } \\
\text { significantly } \\
\text { decreased } \\
\text { compared to the } \\
\text { control group }\end{array}$ & $\begin{array}{l}\text { The findings of } \\
\text { the study } \\
\text { suggested that } \\
\text { supportive } \\
\text { educational } \\
\text { program can } \\
\text { improve physical, } \\
\text { psychological, } \\
\text { spiritual, and } \\
\text { environmental } \\
\text { domains and } \\
\text { overall quality of } \\
\text { life. It can also } \\
\text { decrease the } \\
\text { caring burden in } \\
\text { the family } \\
\text { caregivers of } \\
\text { women with } \\
\text { breast cancer }\end{array}$ & $\begin{array}{l}\text { Small sample size } \\
\text { was used }\end{array}$ \\
\hline Mahadevan & Malaysia & To determine the & A cross-sectional & 130 caregivers & Generally, & There should be & The study was \\
\hline
\end{tabular}


Table 1 Summary of study characteristics and findings (Continued)

\begin{tabular}{|c|c|c|c|c|c|c|c|}
\hline Author/year & Country & $\begin{array}{l}\text { Aim/research } \\
\text { questions }\end{array}$ & Study design & Caregivers & Findings & Conclusion & Limitation \\
\hline $\begin{array}{l}\text { et al. (2013) } \\
\text { [32] }\end{array}$ & & $\begin{array}{l}\text { proportion of } \\
\text { stress among the } \\
\text { caregivers of } \\
\text { breast cancer } \\
\text { patients receiving } \\
\text { oncologic } \\
\text { treatment at Kuala } \\
\text { Lumpur Hospital } \\
\text { and to determine } \\
\text { the predictors of } \\
\text { stress among the } \\
\text { caregivers }\end{array}$ & study & $\begin{array}{l}\text { with mean age of } \\
42.8 \pm 14.5 \text { years }\end{array}$ & $\begin{array}{l}\text { caregivers had } \\
\text { higher levels of } \\
\text { stress. } \\
\text { Approximately } \\
16 \% \text { of caregivers } \\
\text { felt emotionally } \\
\text { strained and 26\% } \\
\text { acknowledge that } \\
\text { taking care of the } \\
\text { patient is hard on } \\
\text { them emotionally. } \\
\text { In addition, } \\
\text { caregivers felt less } \\
\text { in control of their } \\
\text { lives. Caregivers } \\
\text { who looked after } \\
\text { older patients } \\
\text { were less likely to } \\
\text { be stressed }\end{array}$ & $\begin{array}{l}\text { awareness among } \\
\text { medical personnel } \\
\text { about the high } \\
\text { likelihood of stress } \\
\text { among the family } \\
\text { caregivers of } \\
\text { breast cancer } \\
\text { patients and a } \\
\text { heightened } \\
\text { sensitivity to the } \\
\text { caregivers' } \\
\text { emotional } \\
\text { condition. } \\
\text { Caregivers should } \\
\text { have easy access } \\
\text { to mental health } \\
\text { services. There } \\
\text { should be respite } \\
\text { care facilities in } \\
\text { order to relieve } \\
\text { the caregivers } \\
\text { from constant } \\
\text { caregiving burden } \\
\text { and stress }\end{array}$ & $\begin{array}{l}\text { cross-sectional in } \\
\text { design, whereby } \\
\text { being conducted } \\
\text { at one point of } \\
\text { time; no causal re- } \\
\text { lationship can be } \\
\text { inferred between } \\
\text { the outcomes and } \\
\text { the variables. The } \\
\text { application of } \\
\text { non-random sam- } \\
\text { pling method } \\
\text { within a conveni- } \\
\text { ence samples } \\
\text { frame could create } \\
\text { sampling bias, } \\
\text { resulting in over- } \\
\text { or under- } \\
\text { representation of } \\
\text { certain members } \\
\text { of the study } \\
\text { population }\end{array}$ \\
\hline $\begin{array}{l}\text { Yeung et al. } \\
\text { (2018) [30] }\end{array}$ & China & $\begin{array}{l}\text { This study aimed } \\
\text { to examine the } \\
\text { experience of guilt } \\
\text { and its correlates } \\
\text { among Chinese } \\
\text { husbands of } \\
\text { women with } \\
\text { breast cancer }\end{array}$ & $\begin{array}{l}\text { A cross-sectional } \\
\text { survey }\end{array}$ & $\begin{array}{l}176 \text { husbands } \\
\text { caregivers with } \\
\text { mean age of } 50.22 \\
\text { years }\end{array}$ & $\begin{array}{l}\text { Lower } \\
\text { endorsement of } \\
\text { the "masculinity } \\
\text { strength" gender- } \\
\text { role norm, and } \\
\text { higher caregiving } \\
\text { burden and social } \\
\text { support seeking } \\
\text { were associated } \\
\text { with higher care- } \\
\text { giving guilt. Unex- } \\
\text { pectedly, higher } \\
\text { marital satisfaction } \\
\text { and less protective } \\
\text { buffering were as- } \\
\text { sociated with } \\
\text { higher caregiving } \\
\text { guilt. Younger } \\
\text { husband care- } \\
\text { givers in our sam- } \\
\text { ple were more } \\
\text { likely to report } \\
\text { higher guilt. Also, } \\
\text { caregiving burden } \\
\text { was associated } \\
\text { with caregiver } \\
\text { guilt. Also, protect- } \\
\text { ive buffering and } \\
\text { caregiver guilt was } \\
\text { conditional to } \\
\text { caregiver's level of } \\
\text { marital satisfaction }\end{array}$ & $\begin{array}{l}\text { The new findings } \\
\text { and complex } \\
\text { interplay between } \\
\text { caregivers' } \\
\text { characteristics } \\
\text { (including } \\
\text { endorsement of } \\
\text { male gender-role } \\
\text { norms and marital } \\
\text { satisfaction) and } \\
\text { coping strategies } \\
\text { (protective buffer- } \\
\text { ing and seeking } \\
\text { social support) in } \\
\text { predicting guilt } \\
\text { imply that individ- } \\
\text { ual and cultural } \\
\text { characteristics } \\
\text { may change the } \\
\text { effectiveness of } \\
\text { specific coping } \\
\text { strategies in can- } \\
\text { cer caregivers' } \\
\text { well-being }\end{array}$ & $\begin{array}{l}\text { Caregivers were } \\
\text { recruited from } \\
\text { two hospitals. } \\
\text { Hence, sample } \\
\text { may not be } \\
\text { representative of } \\
\text { the total } \\
\text { population of } \\
\text { caregivers of } \\
\text { breast cancer } \\
\text { patients }\end{array}$ \\
\hline $\begin{array}{l}\text { Heidari Gorji } \\
\text { et al. (2012) }\end{array}$ & Iran & $\begin{array}{l}\text { To examine the } \\
\text { correlates of } \\
\text { depression in } \\
\text { relation to quality } \\
\text { of life among } \\
\text { breast cancer } \\
\text { caregivers }\end{array}$ & $\begin{array}{l}\text { A cross-sectional } \\
\text { descriptive design }\end{array}$ & & $\begin{array}{l}\text { Findings were } \\
\text { demonstrated that } \\
\text { high percent of } \\
\text { caregivers were } \\
\text { afflicted by mild } \\
\text { and moderate } \\
\text { depression. The } \\
\text { results showed } \\
\text { that } 42 \text { and } 11 \% \\
\text { reported }\end{array}$ & $\begin{array}{l}\text { The study } \\
\text { demonstrate that } \\
\text { psychological } \\
\text { issues have a } \\
\text { significant impact } \\
\text { on quality of life. } \\
\text { Additionally, help } \\
\text { and attention to } \\
\text { caregivers would } \\
\text { be beneficial in }\end{array}$ & $\begin{array}{l}\text { This is a cross- } \\
\text { sectional study; } \\
\text { hence, results may } \\
\text { not be } \\
\text { generalizable to } \\
\text { all caregivers in } \\
\text { Iran }\end{array}$ \\
\hline
\end{tabular}


Table 1 Summary of study characteristics and findings (Continued)

\begin{tabular}{|c|c|c|c|c|c|c|c|}
\hline Author/year & Country & $\begin{array}{l}\text { Aim/research } \\
\text { questions }\end{array}$ & Study design & Caregivers & Findings & Conclusion & Limitation \\
\hline & & & & & $\begin{array}{l}\text { moderate and low } \\
\text { quality of life, } \\
\text { respectively. The } \\
\text { study demonstrate } \\
\text { that psychological } \\
\text { issues have a } \\
\text { significant impact } \\
\text { on quality of life }\end{array}$ & $\begin{array}{l}\text { improving quality } \\
\text { of life of all family } \\
\text { of patients }\end{array}$ & \\
\hline $\begin{array}{l}\text { Yuanyuan An } \\
\text { et al. (2019) }\end{array}$ & China & $\begin{array}{l}\text { To identify the } \\
\text { influence of family } \\
\text { caregiver's burden } \\
\text { on breast cancer } \\
\text { patient's QoL and } \\
\text { possible mediators }\end{array}$ & $\begin{array}{l}\text { A cross-sectional } \\
\text { design }\end{array}$ & 382 caregivers & $\begin{array}{l}\text { Higher level of } \\
\text { family caregiver's } \\
\text { burden was } \\
\text { associated with } \\
\text { higher levels of } \\
\text { patient's anxiety } \\
\text { and depression }\end{array}$ & $\begin{array}{l}\text { Given the } \\
\text { important role of } \\
\text { family caregiver's } \\
\text { burden, it should } \\
\text { be targeted by } \\
\text { the intervention } \\
\text { aiming to improve } \\
\text { breast cancer } \\
\text { patients' QoL and } \\
\text { well-being }\end{array}$ & $\begin{array}{l}\text { The data were } \\
\text { cross-sectional, } \\
\text { which precludes } \\
\text { conclusions re- } \\
\text { garding causation } \\
\text { and the direction } \\
\text { of relationship } \\
\text { among variables. } \\
\text { Second, the find- } \\
\text { ings are only } \\
\text { generalizable to } \\
\text { the population } \\
\text { studied }\end{array}$ \\
\hline $\begin{array}{l}\text { Nejad et al. } \\
(2016)\end{array}$ & Iran & $\begin{array}{l}\text { Determine and } \\
\text { compare the } \\
\text { caregiver strain } \\
\text { index scores of } \\
\text { breast cancer } \\
\text { informal } \\
\text { caregivers, before } \\
\text { and after a } \\
\text { patient-caregiver } \\
\text { educational and } \\
\text { telephone follow- } \\
\text { up program }\end{array}$ & $\begin{array}{l}\text { Experimental study } \\
\text { design }\end{array}$ & $\begin{array}{l}60 \text { caregivers } \\
\text { Mean age }>30 \\
\text { ( } 28.3 \text { years) } \\
30-50 \text { ( } 43.3 \text { years) } \\
<50 \text { ( } 28.3 \text { years) }\end{array}$ & $\begin{array}{l}\text { The mean } \\
\text { caregiver strain } \\
\text { score of the } \\
\text { intervention } \\
\text { group was } 8.3 \pm 2, \\
\text { and it dropped to } \\
4.8 \pm 2.3 \text { post- } \\
\text { intervention }\end{array}$ & $\begin{array}{l}\text { Caregiver burden } \\
\text { decreased } \\
\text { significantly in the } \\
\text { intervention } \\
\text { group after the } \\
\text { patient-caregiver } \\
\text { education and } \\
\text { follow-up program } \\
(P<0.001)\end{array}$ & $\begin{array}{l}\text { The intervention } \\
\text { period was } \\
\text { relatively short, } \\
\text { thus limiting the } \\
\text { generalizability of } \\
\text { the results }\end{array}$ \\
\hline $\begin{array}{l}\text { Din et al. } \\
\text { (2017) [25] }\end{array}$ & Malaysia & $\begin{array}{l}\text { To determine the } \\
\text { anxiety disorders } \\
\text { specifically } \\
\text { focusing on the } \\
\text { family caregivers } \\
\text { of breast cancer } \\
\text { patients }\end{array}$ & $\begin{array}{l}\text { A cross-sectional } \\
\text { study }\end{array}$ & $\begin{array}{l}130 \text { caregiver- } \\
\text { patient dyads }\end{array}$ & $\begin{array}{l}\text { The study found } \\
\text { that more than a } \\
\text { 10th (11.5\%, } n= \\
\text { 15) of the family } \\
\text { members who } \\
\text { were primarily } \\
\text { involved in caring } \\
\text { for breast cancer } \\
\text { patients had } \\
\text { anxiety disorders. } \\
\text { Specifically, } 8 \\
\text { caregivers (6.1\%) } \\
\text { had generalized } \\
\text { anxiety disorder, } 6 \\
\text { were (4.6\%) } \\
\text { diagnosed to have } \\
\text { panic disorder, } \\
\text { and one (0.8\%) } \\
\text { had social phobia } \\
\text { associated with } \\
\text { both the patients' } \\
\text { type of treatment } \\
\text { and non-shared } \\
\text { caregiving }\end{array}$ & $\begin{array}{l}\text { A multidisciplinary } \\
\text { management } \\
\text { approach should } \\
\text { be extended to } \\
\text { those at risk } \\
\text { which would } \\
\text { directly and } \\
\text { inadvertently } \\
\text { optimize the } \\
\text { treatment care for } \\
\text { patients with } \\
\text { breast cancer }\end{array}$ & $\begin{array}{l}\text { It was cross- } \\
\text { sectional in design } \\
\text { that the direction } \\
\text { of the factors and } \\
\text { the risk factors of } \\
\text { anxiety disorders } \\
\text { could not be } \\
\text { established. The } \\
\text { small sample size } \\
\text { limited the power } \\
\text { of the study to } \\
\text { detect any other } \\
\text { factors particularly } \\
\text { involving the care- } \\
\text { giving process } \\
\text { such as duration } \\
\text { of care that could } \\
\text { have significance } \\
\text { to the anxiety } \\
\text { disorders }\end{array}$ \\
\hline $\begin{array}{l}\text { Khanjari et al. } \\
\text { (2014) [35] }\end{array}$ & Iran & $\begin{array}{l}\text { To explore how } \\
\text { family caregivers } \\
\text { of women with } \\
\text { breast cancer in } \\
\text { Iran describe the } \\
\text { areas in life which } \\
\text { are important to } \\
\text { their quality of life }\end{array}$ & $\begin{array}{l}\text { Descriptive and } \\
\text { prospective cross- } \\
\text { sectional study }\end{array}$ & $\begin{array}{l}88 \text { family } \\
\text { caregivers } \\
\text { consisted of } 29 \\
(33 \%) \text { men and } 59 \\
(67 \%) \text { women } \\
\text { with mean (SD) } \\
41.1 \text { (13.9). }\end{array}$ & $\begin{array}{l}\text { A majority of } \\
\text { family caregivers } \\
\text { reported a high } \\
\text { psychological } \\
\text { impact described } \\
\text { as experiences of } \\
\text { shock and stress, } \\
\text { feeling sadness }\end{array}$ & $\begin{array}{l}\text { Family caregivers } \\
\text { need support in } \\
\text { dealing with the } \\
\text { psychological } \\
\text { strain related to } \\
\text { the situation by } \\
\text { acquiring } \\
\text { information about }\end{array}$ & $\begin{array}{l}\text { Sample size of the } \\
\text { family caregivers is } \\
\text { a limitation to the } \\
\text { study. The use of } \\
\text { semi-structured in- } \\
\text { terviews may not } \\
\text { be as adequate to } \\
\text { capture a }\end{array}$ \\
\hline
\end{tabular}


Table 1 Summary of study characteristics and findings (Continued)

\begin{tabular}{|c|c|c|c|c|c|c|c|}
\hline Author/year & Country & $\begin{array}{l}\text { Aim/research } \\
\text { questions }\end{array}$ & Study design & Caregivers & Findings & Conclusion & Limitation \\
\hline & & $\begin{array}{l}\text { (QoL) and to } \\
\text { determine which } \\
\text { areas in life that } \\
\text { are influenced by } \\
\text { having a family } \\
\text { member with } \\
\text { breast cancer }\end{array}$ & & & $\begin{array}{l}\text { and depressed, } \\
\text { fear and anxiety, } \\
\text { and having } \\
\text { disturbed sleep. } \\
\text { Furthermore, } \\
\text { family caregivers } \\
\text { stated other } \\
\text { aspects which } \\
\text { may have a } \\
\text { negative impact } \\
\text { on mental and } \\
\text { emotional well- } \\
\text { being but not } \\
\text { covered, namely, } \\
\text { descriptions of } \\
\text { fear of recurrence, } \\
\text { uncertainty of out- } \\
\text { come, and worry } \\
\text { about future and } \\
\text { death. Many fam- } \\
\text { ily caregivers re- } \\
\text { ported a change } \\
\text { in their relation- } \\
\text { ship with their sick } \\
\text { relative and that } \\
\text { the disease } \\
\text { tended to amplify } \\
\text { existing problems. } \\
\text { Religious aspects } \\
\text { such as feeling a } \\
\text { stronger connec- } \\
\text { tion to God as } \\
\text { well as optimism } \\
\text { and hope were } \\
\text { expressed to be } \\
\text { enhanced for } \\
\text { some of the family } \\
\text { caregivers }\end{array}$ & $\begin{array}{l}\text { cancer and its } \\
\text { treatment and in } \\
\text { how to } \\
\text { communicate } \\
\text { about their own } \\
\text { concerns with } \\
\text { their relative with } \\
\text { cancer. Moreover, } \\
\text { education and } \\
\text { interventions from } \\
\text { health care } \\
\text { professionals } \\
\text { would be } \\
\text { beneficial in } \\
\text { improving QoL for } \\
\text { the families of } \\
\text { patients }\end{array}$ & $\begin{array}{l}\text { phenomenon as } \\
\text { more in-depth } \\
\text { interviews }\end{array}$ \\
\hline $\begin{array}{l}\text { Kusi et al. } \\
\text { (2020) [4] }\end{array}$ & Ghana & $\begin{array}{l}\text { To explore the } \\
\text { caregiving } \\
\text { motivations and } \\
\text { experiences of } \\
\text { family caregivers } \\
\text { of patients living } \\
\text { with advanced } \\
\text { breast cancer }\end{array}$ & $\begin{array}{l}\text { Exploratory } \\
\text { descriptive } \\
\text { phenomenological } \\
\text { approach }\end{array}$ & $\begin{array}{l}15 \text { caregivers. } 7 \\
\text { were males while } \\
8 \text { were females } \\
\text { with age range } \\
\text { from } 25 \text { to } \\
73 \text { years. }\end{array}$ & $\begin{array}{l}\text { Caregivers were } \\
\text { involved in } \\
\text { bathing, } \\
\text { grooming, and } \\
\text { cooking for } \\
\text { patients. Their } \\
\text { experiences } \\
\text { further include } \\
\text { symptom } \\
\text { management such } \\
\text { as the } \\
\text { management of } \\
\text { pain, } \\
\text { lymphedema, } \\
\text { wound, and } \\
\text { evaluation of } \\
\text { symptoms. } \\
\text { Caregivers were } \\
\text { the main } \\
\text { providers of } \\
\text { emotional support } \\
\text { by offering } \\
\text { patients with } \\
\text { words of } \\
\text { encouragement. } \\
\text { They also } \\
\text { experience } \\
\text { financial burden } \\
\text { by providing out- }\end{array}$ & $\begin{array}{l}\text { There is the need } \\
\text { for home-based } \\
\text { support programs } \\
\text { to assist caregivers } \\
\text { in their caring role } \\
\text { especially in the } \\
\text { area of symptom } \\
\text { management and } \\
\text { direct governmen- } \\
\text { tal social interven- } \\
\text { tion programs } \\
\text { (e.g., transporta- } \\
\text { tion to treatment } \\
\text { facilities and drugs } \\
\text { for patients) to } \\
\text { resource-limited } \\
\text { caregiving families } \\
\text { of women with } \\
\text { advanced breast } \\
\text { cancer. The Na- } \\
\text { tional Health In- } \\
\text { surance Scheme } \\
\text { should be ex- } \\
\text { panded to fully } \\
\text { cover breast can- } \\
\text { cer treatment to } \\
\text { women and their } \\
\text { family caregivers }\end{array}$ & $\begin{array}{l}\text { The findings } \\
\text { cannot be } \\
\text { generalized based } \\
\text { on the sample } \\
\text { selection } \\
\text { (caregivers of only } \\
\text { advanced breast } \\
\text { cancer patients). } \\
\text { The study was } \\
\text { limited to a single } \\
\text { site }\end{array}$ \\
\hline
\end{tabular}


Table 1 Summary of study characteristics and findings (Continued)

\begin{tabular}{|c|c|c|c|c|c|c|c|}
\hline Author/year & Country & $\begin{array}{l}\text { Aim/research } \\
\text { questions }\end{array}$ & Study design & Caregivers & Findings & Conclusion & Limitation \\
\hline & & & & & $\begin{array}{l}\text { of-pocket money } \\
\text { for treatment } \\
\text { costs and other } \\
\text { related non- } \\
\text { medical costs }\end{array}$ & & \\
\hline
\end{tabular}

the remaining $(n=4)$ were qualitative studies $[4,6,17$, 29]. Studies were conducted in the following countries: Nigeria $(n=2)$, Malaysia $(n=3)$, Ghana $(n=1)$, China $(n=3)$, Iran $(n=6)$, Turkey $(n=1)$, Mexico $(n=1)$, Indonesia $(n=1)$, and India $(n=1)$.

A total of 2330 family caregivers were included in the studies. The sample sizes within the included studies ranged from 7 caregivers [17, 29] to 384 caregivers [26]. The disease severity of the patients being cared for by the caregivers was only stated in 10 studies [4, 15, 24, 26, 28-32, 34].

Table 1 shows the summary of the included studies on caregivers' experiences of women diagnosed with breast cancer.

\section{Quality appraisal or assessment of included studies}

Quality appraisal of the included works of literature using MMAT ranged from moderate (50\%) to strong quality (100\%). Two studies were rated as strong quality $[4,6]$. Fifteen studies were scored as moderate-strong quality $[15,18,19,23-33,35]$, and the remaining two studies $[3,17]$ were scored as moderate. None of the included studies was excluded based on their quality assessment score. The level of agreement of quality ratings between the two independent raters ranged from strong [kappa 0.79; 95\% (0.4-1.2); $p=0.001]$ to excellent agreement [kappa 1.0; 95\% (0.9-1.0); $p=0.001]$. Table 2 shows the quality assessment of the included studies.

\section{Findings on the caregivers' experiences}

The synthesis of the included articles showed that caregivers' experiences fell into 10 main categories, namely, (1) caregivers' motivation, (2) roles of family caregivers, (3) quality of life among caregivers, (4) physical burden of caregiving, (5) psychological burden of caregiving, (6) disruption in social life, (7) economic burden of caregiving, (8) need for support, (9) interventions for improving caregiver experience, and lastly (10) coping. These findings are described in the ensuing paragraphs.

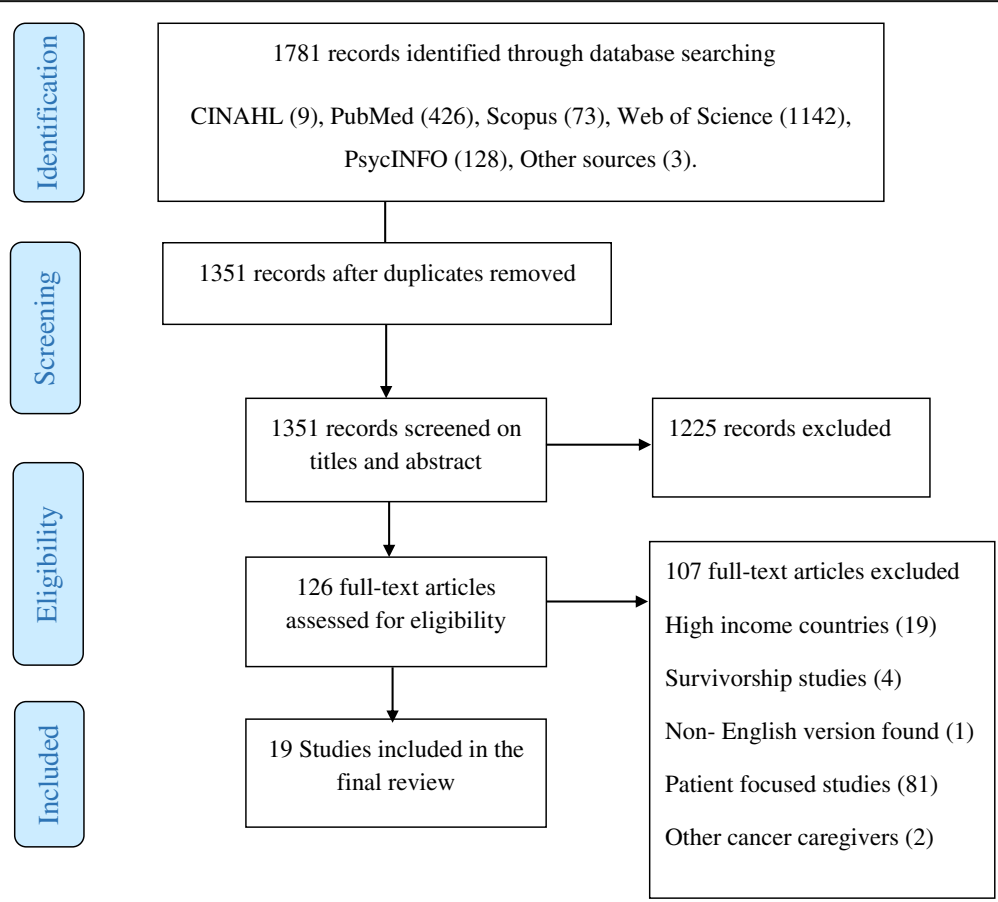

Fig. 1 PRISMA flow diagram showing the systematic screening process 


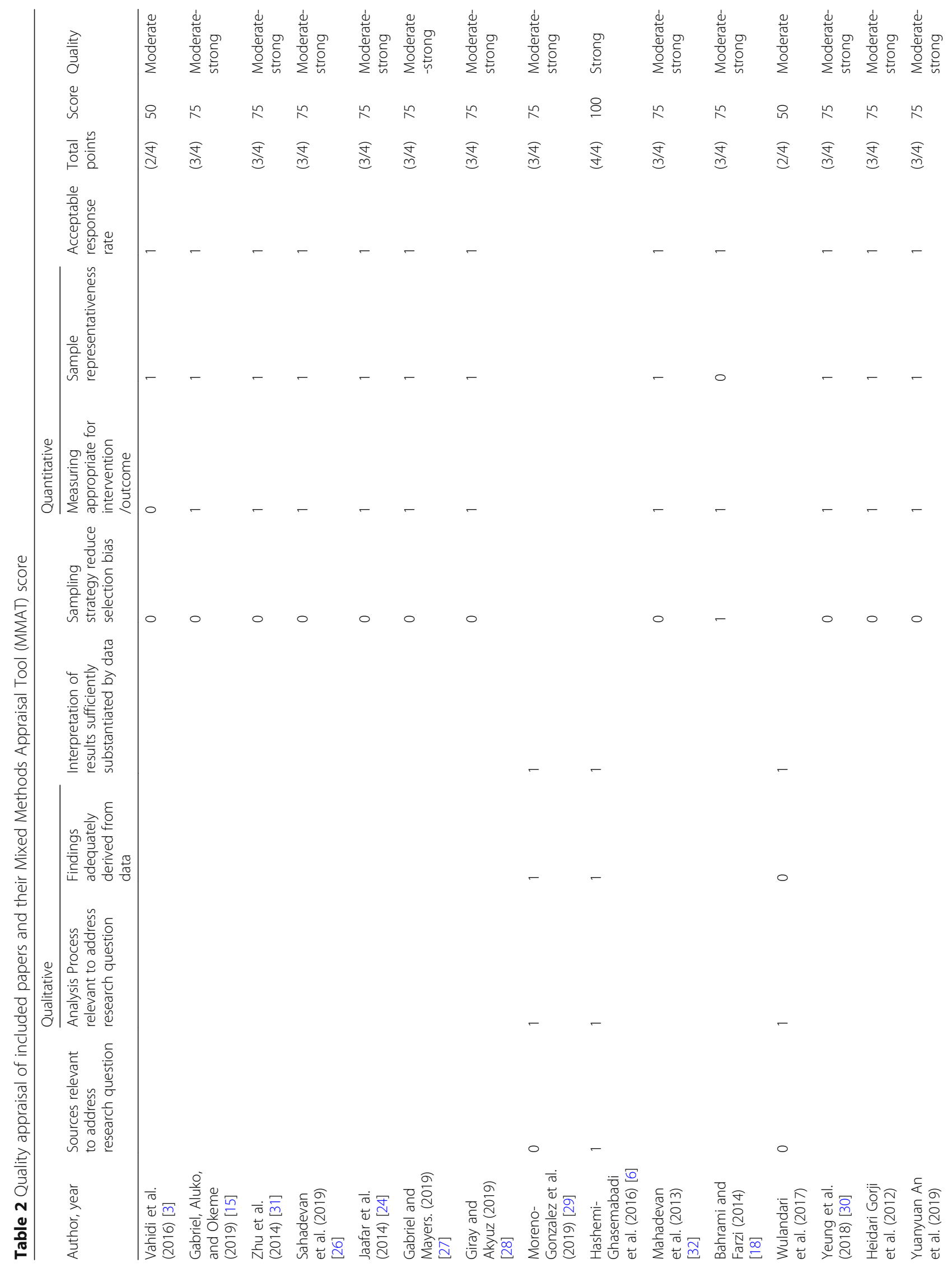




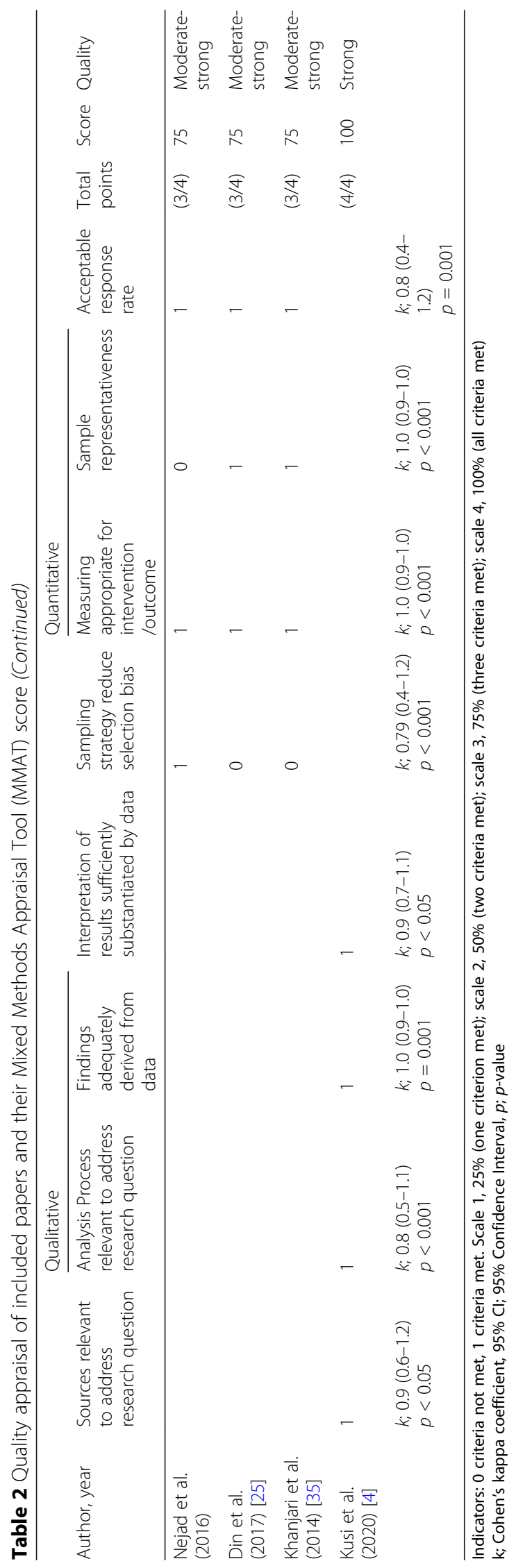




\section{Caregivers' motivation}

Three studies focused on the caregivers' motivation for delivering care to women with breast cancer $[4,6,30]$. In the first study, caregivers cited a sense of responsibility and commitment as forms of motivation for their caregiving roles [6]. One Ghanaian study reported that family and sociocultural obligations prompted family members, especially females, to assume the caregiving role for women with breast cancer [4]. However, two studies conducted in Ghana [4] and China [30] reported that family-oriented cultural norms also prompted males such as spouse caregivers to assume the role of primary caregivers.

\section{Roles of family caregivers}

Four studies emphasized the role of caregivers in the management of breast cancer [3, 4, 26, 29]. Vahidi et al. [3] and Kusi et al. [4] suggested that caregivers played key roles in assisting patients with activities of daily living and the administration of medications. The studies also showed that caregivers played roles in assisting with treatment decision-making and symptom management [3, 4, 26, 29]. Moreno-González et al. [29] and Kusi et al. [4] also emphasized that caregivers managed specific symptoms such as breast wound and lymphedema, evaluation of symptoms, and management of pain. One study also reported that caregivers were the primary source of psychosocial, spiritual, and financial support for women with breast cancer [4].

\section{Quality of life among caregivers}

Seven articles gave an account of the quality of life of caregivers. The reports indicated that caregivers of women diagnosed with breast cancer had low levels of quality of life as compared to the general healthy population $[3,15,23,26,28,31,33]$. One study reported that the patient correlates of poor quality of life among family caregivers were advanced-stage breast cancer, poor functional status, frequent hospitalization, longer duration of breast cancer [15], lack of transportation [3], and high symptom burdens such as wound [31] and postmastectomy lymphedema [28]. Further, An et al. [23] also cited that higher levels of anxiety and depression were associated with poor quality of life among caregivers. Lastly, three studies highlighted that lack of formal support services that characterized developing countries also resulted in poor quality of life among caregivers $[3,10,33]$.

\section{Physical burden of caregiving}

Four studies emphasized that caregivers reported a moderate to severe decline in physical health $[6,10,17,31]$. Altered sleep patterns and hypertension were the frequently reported physical symptoms experienced by the caregivers [6, 10, 17]. Zhu et al. also highlighted that low family income and increasing age are predictors of physical burden among caregivers [31].

\section{Psychological burden of caregiving}

The majority of the included studies reported that psychological burden was the most frequent stressor that caregivers encountered [6, 10, 17, 25-27, 29-33]. According to Khanjari et al. [10], more than $70 \%$ of family caregivers experienced severe psychological impacts 6 months following breast cancer diagnosis and the assumption of the caregiving role. These studies also identified some conditions described as psychological burdens among the caregivers. Six studies cited depression as a common psychological burden among caregivers [10, 24, 30-33]. Studies cited that factors such as age [32], male gender, altered sleeping pattern $[10,17$, $30,31]$, longer duration of caregiving [24, 26, 32], lower educational level, not sharing caregiving responsibilities [32], and decreased functional status of patients [24, 32] were significantly associated with stressors such as depression among caregivers. Additionally, anxiety had also been identified as a common psychological distress that is experienced by caregivers $[17,25]$. According to Din et al., about one third of caregivers suffered from anxiety-related disorders [25]. Furthermore, Din et al. [25] reported that longer caregiving duration and absence of shared caregiving were significantly associated with anxiety disorders. Moreover, four of the included studies reported that anxiety among caregivers was caused by the uncertainties of breast cancer outcomes, fear of recurrence, and poor financial supports available to caregivers [10, 17, 25, 26, 29]. Several emotional traumas such as fear, shock, anger, and sadness were also cited by caregivers in three studies [6,26,29].

\section{Disruption in social life}

Hashemi-Ghasemabadi et al. [6] reported that caregivers experienced a loss of normal life. This study also reported that caregivers experienced deteriorating relationships with other family members. Some caregivers cited that they felt isolated and lacked support from family and friends, which increased the burden associated with their caregiving roles [6].

\section{Economic burden of caregiving}

Eight papers examined the economic burden associated with caregiving around breast cancer $[3,6,10,15,17$, $24,27,29]$. Two studies reported that caregivers usually decreased their working hours or lost paid jobs as a result of the caregiving role $[17,24]$. It was also reported that even in conditions where caregivers still engaged in paid jobs, high treatment costs coupled with the absence of fully financed healthcare system that exists in LMICs 
created a high economic burden for family caregivers $[15,17,24,27,29]$. The synthesized findings also showed that lack of basic financial resources $[15,29]$ and inadequate income for meeting caregiving demands $[3,6,10$, 27] also resulted in financial burden for caregivers. Further, Gabriel and Mayers [27] suggested that given the extreme financial burden that is faced by caregivers in developing countries, educational interventions might be ineffective in improving the financial well-being among caregivers.

\section{The need for support}

The need for social support was the most frequent need that was cited by the caregivers across six included studies $[6,17,25,29-31]$. Caregivers cited that they had not received adequate social support from their families and friends $[17,25,31]$. Specifically, caregivers described the need for sharing caregiving responsibilities with other family members and friends $[6,25,30,31]$.

Nonetheless, Yeung et al. [30] and Vahidi et al. [3] reported that seeking support from families and friends among spouse caregivers may result in increased emotional distress as it may be culturally interpreted as a sign of weakness and lack of self-confidence. Further, in three studies, caregivers also stressed the importance of support from the formal care systems to help them manage patients' symptoms in the home setting $[6,17,29]$.

\section{Interventions for improving the caregiver's experience}

Three articles examined interventions to support family caregivers [18, 19, 27]. Largely, all the studies reported significant improvement in the quality of life after psycho-educational intervention. Particularly, the improvements in caregivers' quality of life were related to measures such as the emotional aspect of caregiving. In the first study [27], it was reported that caregivers were given psycho-educational interventions to improve their quality of life. Caregivers in the interventional group received 6 weeks of information about adjustment to the role of family caregivers and strategies to deal with the emotional aspects of caregiving. This quasi-experimental study reported that caregivers in the interventional group reported better quality of life after the 6 weeks [27]. It was reported that the provision of informational support aided in decreasing caregiving burden among the caregivers. However, the intervention did not affect the financial well-being of caregivers.

The second education intervention study [18] examined the effect of a supportive educational program on the caring burden and quality of life of family caregivers. The intervention group in this study reported a clear increase in caregivers' knowledge about breast cancer management, physical, psychological, spiritual, and environmental dimensions of health. Lastly, the third study
[19] evaluated the effect of an educational and telephone follow-up on caregiver burden. Results from this showed that caregiver burden decreased significantly among the intervention group.

\section{Coping}

Three of the included studies reported on coping strategies used by family caregivers $[10,17,29]$. These studies reported that religious coping such as putting one's faith in God was vital in improving the quality of life among caregivers $[10,17,29]$. Two of the studies further reported that caregivers reported that being religious provided them with meaning in their caregiving roles $[10,17]$. Further, one study also showed that previous knowledge on breast cancer aided caregivers to cope effectively in their caring role [29].

\section{Discussion}

In this systematic review, key evidence on family caregivers of women diagnosed with breast cancer in LMICs has been highlighted. Reviews focusing on caregivers of women with breast cancer in LMICs are missing in the literature. The current systematic review, therefore, addressed this gap by adding to the knowledge in this area.

The current review demonstrated that family members, including male spouses, assumed the caregiving role for women diagnosed with breast cancer. Based on this finding, future research using comparative study designs should be conducted to examine how breast cancer caregiving differs among male and female caregivers. This systematic review further highlighted the roles that are played by family caregivers in providing physical, spiritual, emotional, and financial support to women with breast cancer in LMICs [3, 4]. Furthermore, studies in this review highlighted the significant role played by caregivers in symptom management $[3,4,26]$. Despite this important finding, only one of the included studies [4] provided information on how symptoms such as pain, lymphedema, and breast wound are managed in the home by the caregivers. The level of empirical evidence addressing how family caregivers manage symptoms in LMICs where there is evidence of limited formal support structures needs further exploration using qualitative methods.

The review identified a range of burdens that are encountered by caregivers. Caregivers reported challenges such as fear, depression, and hypertension [6, 25, 31]. Financial challenges such as lack of transportation, loss of a paid job, and high treatment cost were also fundamental sources of stress for caregivers across several studies in this review [3, 26, 27, 29]. This finding is expected, considering the financial burden that such caregiver roles put on families. This is because these caregivers are already overburdened by the lack of formal support 
services and poor economic status in LMICs. Therefore, these identified challenges encountered by the caregivers in LMICs in their caregiving roles represent areas in the caregivers' lives that need to be addressed in policy formulation.

Also, it was reported that disease severity and declining functional status impacted the quality of life of the caregivers [3, 15, 26, 31]. As such, how the caregivers' challenges change according to the progression of breast cancer is an important topic for further exploration in future longitudinal studies.

The findings of this review also showed that educational and psychological interventions could prove as relevant tools in improving the wellbeing of family caregivers $[18,19,27]$. Accordingly, it would be important for future study to focus on the development of educational and supportive interventions for family caregivers to help address their challenges.

One of the most striking gaps observed in this systematic review is the lack of qualitative studies on the caregivers of women with breast cancer in LMICs. Only four studies explored the experiences and challenges that were faced by the caregivers in their caregiving roles using qualitative designs $[4,6,17,29]$. This finding therefore offers opportunity for further qualitative works into breast cancer caregiving in LMICs. This method of enquiry will produce a rich, detailed, and rigorous data on the phenomenon by allowing participants to naturally share their lived experiences in their setting.

Lastly, there are a few studies that explored other aspects of caregiver wellbeing such as disruption in social life, coping measures, and intervention for caregivers [6]. Therefore, a need exists to focus future studies on these areas of the caregiver wellbeing.

\section{Strengths and limitations}

Some limitations of this systematic review are worth noting. First, this review found a relatively small number of relevant studies. With a publication period from January 2000 to March 2020, only 19 studies that had reported on family caregivers of breast cancer patients were identified and synthesized. This may hinder the generalizability of the research findings. However, with expanded attention to breast cancer caregivers in LMICs, this review can drive future research and also inform policy. Further limitation is language restriction. Non-English language articles were excluded due to the limited capacity to access professional language services. This is challenging since family caregiving in breast cancer is sociocultural and context-specific. Excluding articles in non-English languages may have resulted in a limited understanding of the phenomenon under review and therefore poses a risk of bias in extrapolating the results to a broader population. Further, not considering studies that had been published in the developed countries might have resulted in the exclusion of relevant studies.

In addition, it was not feasible to synthesize the results in a meta-analysis as the included studies were clearly heterogenous. For instance, the included studies used different methods such as correlational studies, crosssectional designs, and self-reported data to obtain caregivers' reported experiences. It was however decided a priori to include all studies regardless of their study design as the aim of this study was to investigate the diversity of studies reporting on caregivers of women living with breast cancer in LMICs, thus obtaining a broad perspective of the phenomenon under review.

The strength of this systematic review includes the use of an MMAT tool for the quality appraisal by two independent reviewers. Also, we are the first to systematically map evidence and report on the experiences of family caregivers of breast cancer patients in low- and middle-income countries.

\section{Conclusions}

The incidence of breast cancer is increasing in LMICs. This has serious implications for family caregivers. The burden associated with the caregiving role is further amplified by limited availability and access to palliative services and formal structures to support caregivers in their caring roles. Also, due to factors such as financial constraints, there may be a lack of social protection policies for breast cancer caregivers. The high psychological and financial burdens associated with caregiving in developing countries create the need to raise awareness about the neglected needs of family caregivers.

Enhanced support for caregivers should be highlighted as a priority in LMICs. There are numerous gaps in policy and education about caregivers that need to be addressed. The available evidence in this review does not comprehensively address how caregiver challenges can be reduced. Therefore, further research is needed to generate empirical data to inform an evidence-based approach to addressing family caregivers' challenges in LMICs.

\section{Contribution of the paper \\ What is known about this topic?}

- Breast cancer is a common malignancy among women in LMICs.

- There is a transition of breast cancer treatment from the in-patient setting to the out-patient setting. 


\section{What this paper adds:}

- Evidence on family caregivers of breast cancer patients in LMICs.

- Identify the limited evidence and the existing gaps in research related to breast cancer caregiving that urgently needs to be addressed.

- Family caregivers play a key role in providing home care for breast cancer patients in LMICs.

- Family caregivers experience challenges in their caregiving role.

\section{Supplementary information}

Supplementary information accompanies this paper at https://doi.org/10. 1186/s13643-020-01408-4.

Additional file 1: Table S1. Search strategy.

\section{Abbreviations}

LMICS: Low-and middle-income countries; MMAT: Mixed Methods Appraisal Tool

\section{Acknowledgments}

None.

\section{Authors' contributions}

GK: conceptualization, design, literature search, review/screening of articles, drafting of the original manuscript, review, editing, and approval of the manuscript for publication. ABBM: conceptualization, design, supervision, literature search, review/screening of articles, drafting of the original manuscript, review, editing, and approval of the manuscript for publication. KBM: literature search, review/screening of articles, review, editing, and approval of the manuscript for publication. All other authors: review, editing, and approval of the manuscript for publication.

\section{Funding}

The authors have no funding support for this study.

\section{Availability of data and materials}

All data generated or analyzed during this study are included in this published article (and its supplementary information files). The data can be accessed at figshare data repository through https://doi.org/10.6084/m9. figshare.12089205.

\section{Ethics approval and consent to participate}

Not applicable.

\section{Consent for publication}

Not applicable.

\section{Competing interests}

The authors declare that they have no competing interests.

\section{Author details}

'Department of Nursing, Faculty of Allied Health Sciences, College of Health Sciences, Kwame Nkrumah University of Science and Technology, Kumasi, Ghana. ${ }^{2}$ Department of Obstetrics and Gynecology, Komfo Anokye Teaching Hospital, Kumasi, Ghana. ${ }^{3}$ Oncology Directorate, Komfo Anokye Teaching Hospital, Kumasi, Ghana. ${ }^{4}$ Department of Pharmacy Practice, Faculty of Pharmacy and Pharmaceutical Sciences, Kwame Nkrumah University of Science and Technology, Kumasi, Ghana.
Received: 19 September 2019 Accepted: 10 June 2020

Published online: 23 July 2020

\section{References}

1. Shafaie FS, Mirghafourvand M, Amirzehni J. Predictors of quality of life in patients with breast cancer. Indian J Palliat Care. 2019;25:73.

2. Rivera-Franco MM, Leon-Rodriguez E. Delays in breast cancer detection and treatment in developing countries. Breast Cancer Basic Clin Res. 2018;12: 117822341775267. https://doi.org/10.1177/1178223417752677.

3. Vahidi M, Mahdavi N, Asghari E, Ebrahimi H, Ziaei JE, Hosseinzadeh M, et al. Other side of breast cancer: factors associated with caregiver burden. Asian Nurs Res (Korean Soc Nurs Sci). 2016;10:201-6. https://doi.org/10.1016/j.anr. 2016.06.002.

4. Kusi G, Boamah Mensah AB, Boamah Mensah K, Dzomeku VM, Apiribu F, Duodu PA. Caregiving motivations and experiences among family caregivers of patients living with advanced breast cancer in Ghana. PLoS One. 2020;15:e0229683. https://doi.org/10.1371/journal.pone.0229683.

5. Zelle S, Nyarko K, Bosu W, Aikins M, Niëns L, Lauer J, et al. Costs, effects and cost-effectiveness of breast cancer control in Ghana. Trop Med Int Heal. 2012;17:1031-43.

6. Hashemi-Ghasemabadi M, Taleghani F, Yousefy A, Kohan S. Transition to the new role of caregiving for families of patients with breast cancer: a qualitative descriptive exploratory study. Support Care Cancer. 2016; 24: 1269-76. https://doi.org/10.1007/s00520-015-2906-3.

7. Muliira JK, Kizza IB, Nakitende G. Roles of family caregivers and perceived burden when caring for hospitalized adult cancer patients: perspective from a low-income country. Cancer Nurs. 2019;42:208-17.

8. Alexander A, Kaluve R, Prabhu J, Korlimarla A, Srinath B, Manjunath S, et al. The impact of breast cancer on the patient and the family in Indian perspective. Indian J Palliat Care. 2019;25:66-72.

9. Ozaki A, Tsubokura M, Leppold C, Sawano T, Tsukada M, Nemoto T, et al. The importance of family caregiving to achieving palliative care at home: a case report of end-of-life breast cancer in an area struck by the 2011 Fukushima nuclear crisis: a case report. Medicine (Baltimore). 2017;96:e8721. https://doi.org/10.1097/MD.0000000000008721.

10. Khanjari S, Langius-Eklöf A, Oskouie F, Sundberg K. Family caregivers of women with breast cancer in Iran report high psychological impact six months after diagnosis. Eur J Oncol Nurs. 2014.

11. Chronopoulou K, Sakkas D, Damigos D. Caregiving burden and psychological distress of breast cancer patients' husbands after mastectomy. Int J Caring Sci. 2016;9:909-13 http://www. internationaljournalofcaringsciences.org/docs/19_chronopoulou_originial_ 9_3.pdf.

12. Fekih-Romdhane F, Henchiri H, Ridha R, Labbane R, Cheour M. Level of psychological distress and perceived distress and perceived burden among spouses of women with breast cancer. Encephalon. 2019;45:190-2. https:// doi.org/10.1016/j.encep.2018.09.003.

13. Holst-Hansson A, Idvall E, Bolmsjo I, Wennick A. Hoping to reach a safe haven - Swedish families' lived experiences when a family member is diagnosed with breast cncer. Eur J Oncol Nurs. 2017;31:52-8. https://doi. org/10.1016/j.ejon.2017.10.003.

14. Cheng T, Jackman M, Mcquestion M, Fitch M. 'Knowledge is power' perceived needs and preferred services of male partners of women newly diagnosed with breast cancer; 2014. p. 474. https://doi.org/10.1007/s00520014-2314-0.

15. Gabriel I, Aluko J, Okeme M. Caregiver burden among informal caregivers of women with breast cancer. Biomed J Sci Tech. 2019;15:1-9. https://doi.org/ 10.26717/BJSTR.2019.15.002704.

16. World Bank Groupplu. World Bank Country and Lending Groups. The World Bank. http://datahelpdesk.worldbank.org/knowledgebase/articles/906519world-bank-country-and-lending-groups. Accessed 15 Mar 2020.

17. Wulandari SK, Hermayanti Y, Yamin A, Efendi F, Padjadjaran U, Airlangga U. Family process with breast cancer patient (Sarah Kartika Wulandari et al.). 2015;:180-8. http://eprints.ners.unair.ac.id/494/1/breast cancer.pdf.

18. Bahrami M, Farzi S. The effect of a supportive educational program based on COPE model on caring burden and quality of life in family caregivers of women with breast cancer. Iran J Nurs Midwifery Res 2014;19:119-126. http://www.ncbi.nlm.nih.gov/pubmed/24834079\%0A, http://www. pubmedcentral.nih.gov/articlerender.fcgi?artid=PMC4020019. Accessed 7 Dec 2019. 
19. Kochaki Nejad Z, Aghdam AM, Hassankhani H, Sanaat Z. The effects of a patient-caregiver education and follow-up program on the breast cancer caregiver strain index. Iran Red Crescent Med J. 2016;18:e21627.

20. Pluye P, Gagnon MP, Griffiths F, Johnson-Lafleur J. A scoring system for appraising mixed methods research, and concomitantly appraising qualitative, quantitative and mixed methods primary studies in mixed studies reviews. Int J Nurs Stud. 2009;46:529-46.

21. Pace R, Pluye P, Bartlett G, Macaulay A, Salsberg J, Jagosh J, et al. Testing the reliability and efficiency of the pilot mixed methods appraisal tool (MMAT) for systematic mixed studies review. Int J Nurs Stud. 2012;49:47-53.

22. McHugh ML. Lessons in biostatistics interrater reliability: the kappa statistic Biochem Medica. 2012;22:276-82 https://hrcak.srce.hr/89395. Accessed 18 Nov 2019.

23. An Y, Fu G, Yuan G. Quality of life in patients with breast cancer: the influence of family caregiver's burden and the mediation of patient's anxiety and depression. J Nerv Ment Dis. 2019;207:921-6.

24. Jaafar NRN, Din SHS, Zakaria H, Saini SM, Ahmad SNA, Midin M, et al. Clinical depression while caring for loved ones with breast cancer. Compr Psychiatry 2014;55:S52-S59. https://doi.org/10.1016/j.comppsych.2013.03.003.

25. Din SHS, Jaafar NRN, Zakaria H, Saini SM, Ahmad SNA, Midin M. Anxiety disorders in family caregivers of breast cancer patients receiving oncologic treatment in Malaysia. 2017;18:465-71. https://doi.org/10.22034/APJCP.2017. 18.2.465.

26. Sahadevan S, Namboodiri V. Depression in caregivers of patients with breast cancer. Indian J Psychiatry. 2019;61:277. https://doi.org/10.4103/psychiatry. IndianJPsychiatry_46_18

27. Gabriel I, Mayers P. Effects of a psychosocial intervention on the quality of life of primary caregivers of women with breast cancer. Eur J Oncol Nurs. 2019;38:85-91. https://doi.org/10.1016/j.ejon.2018.12.003.

28. Giray E, Akyuz G. Assessment of family caregiver burden and its relationships between quality of life, arm disability, grip strength, and lymphedema symptoms in women with postmastectomy lymphedema: a prospective cross-sectional study. Eur J Breast Heal. 2019;15:111-8.

29. Moreno-González MM, Galarza-Tejada DM, Tejada-Tayabas LM. Experiencias del cuidado familiar durante el cáncer de mama: la perspectiva de los cuidadores. Rev Esc Enferm USP. 2019;53:e03466.

30. Yeung N, Zhang Y, Ji Y, Lu G, Lu Q. Guilt among husaband caregivers of Chinese women with breast cancer: the roles of male gender-role norm, caregiving burden and coping processes. Eur J Cancer Care (Engl). 2018;27: e12872.

31. Zhu P, Fu J, Wang B, Lin J, Wang Y, Fang N, et al. Quality of life of male spouse caregivers for breast cancer patients in China. 2014;15:4181-5. https://doi.org/10.7314/APJCP.2014.15.10.4181.

32. Mahadevan R, Jaafaraafar NRN, Din SHS, Ahmad SNA, Baharuddin A, Razali R. The stress of caregiving: a study of family caregivers of breast cancer patients receiving oncologic treatment at a Malaysian general hospital. Sains Malaysiana. 2013;42:1019-26.

33. Ali M, Gorji H, Bouzar Z, Haghshenas M, Kasaeeyan AA. Quality of life and depression in caregivers of patients with breast cancer. ? 2012;5:1. https:// doi.org/10.1186/1756-0500-5-310.

34. Laryea DO, Awuah B, Amoako YA, Osei-Bonsu E, Dogbe J, Larsen-Reindorf R, et al. Cancer incidence in Ghana, 2012: evidence from a population-based cancer registry. BMC Cancer. 2014;14:382.

35. Khanjari S, Langius-Eklöf A, Oskouie F, Sundberg K. Family caregivers of women with breast cancer in Iran report high psychological impact six months after diagnosis. Eur J Oncol Nursing. 2014;18:630-5.

\section{Publisher's Note}

Springer Nature remains neutral with regard to jurisdictional claims in published maps and institutional affiliations.

Ready to submit your research? Choose BMC and benefit from:

- fast, convenient online submission

- thorough peer review by experienced researchers in your field

- rapid publication on acceptance

- support for research data, including large and complex data types

- gold Open Access which fosters wider collaboration and increased citations

- maximum visibility for your research: over $100 \mathrm{M}$ website views per year

At BMC, research is always in progress.

Learn more biomedcentral.com/submissions 